\title{
Republicanism and the all subjected principle as the basis of democratic membership
}

\author{
Iseult Honohan
}

\section{Introduction}

In his illuminating essay Rainer Bauböck advances a comprehensive approach to the question of how to determine membership of a democratic political community, that takes into account alternative theoretical principles, a variety of kinds of contemporary membership claims, and the complexities of current multiple levels of political structures.

He identifies his all citizen stakeholders (ACS) approach as broadly republican, concerned with individual and collective self-government by those who have a stake in the polity's future because of the circumstances of their lives. "Citizens are stakeholders in a democratic political community insofar as their autonomy and well-being depend not only on being recognized as a member in a particular polity, but also on that polity being governed democratically" (p. 41). Thus the essay combines arguments associated with membership of the demos with others concerning the grounds for citizenship.

Bauböck proposes that ACS is better able than two other principles advanced in democratic theory - the all affected interests (AAI) and all subject to coercion (ASC) principles - to subsume a range of justified claims to membership. Those norms are depicted not so much as wrong but as incomplete to cover all claims for democratic inclusion. They "cannot be accepted as comprehensive answers to the democratic boundary problem, since they fail to provide a principle for the legitimate constitution of such polities and claims to inclusion in them" (p. 27). 
Thus they are to be seen less as rival alternative justifying principles for defining the demos than as complementary to the more comprehensive citizen stakeholder approach.

Thus, in his account, each principle has a particular focus - on interests, on protection and on citizenship - that is appropriate at different levels:

Those whose interests are affected by a decision have a democratic claim that their interests be taken into account in the process of decisionmaking and implementation. Those who are subjected to the jurisdiction of a polity have a democratic claim to equal protection under the law. And those who have a legitimate stake in participating in the selfgovernment of a particular polity have a democratic claim to be recognized as citizens. (p. 20)

In my response, I do not attempt to provide anything like a systematic alternative account of democratic membership to that proposed by Bauböck, who has developed a unique theoretical account that gives due consideration to a dense array of both normative and empirical factors at multiple levels. I simply sketch the lineaments of an all subjected account of the demos that provides for republican self-government. This aims to redeem the power of the all subjected principle to define the demos, and suggests that there is more continuity between the demos based on this principle and that referring to citizenship stakeholders.

There is a great deal that can be accepted in Bauböck's account, including many of the framing assumptions of the discussion. My queries arise mainly from the way in which the theoretical principles justifying claims to membership of the demos are characterized and distinguished, and in particular how the all subjected principle is seen in terms of a purely protective neo-republicanism, which is distinguished from the democratic republican self-government of citizenship stakeholding. I re-examine the interpretation of the neo-republican non-domination account that Bauböck associates with the all subjected principle. I suggest that, if we see the underlying problem of subjection to coercion as 
domination, this focuses on continuing subjection, and requires more than protection. Moreover, when domination is interpreted in terms of the imposition of arbitrary will rather than a failure to track interests, neo-republicanism lends itself to an emphasis on self-government. The connection between non-domination and autonomy leads beyond domination to the kind of self-government among related individuals that Bauböck associates with his citizenship stakeholder account. On this basis, I propose an account of ASC that focuses on continuing subjection to a political authority, which, if it is not to be dominating, requires secure protection and facilitates autonomy, personal and political. I argue that a modified version of the all subjected principle escapes a number of the criticisms levelled at it, and provides a clear basis for membership of the demos. Finally, I offer future continuing subjection as a more defensible basis for birthright citizenship while ensuring the continuity of the democratic political community. This may be seen less as a criticism of Bauböck's analysis than as a qualification, strengthening the case for the all subjected principle as a clear principle of membership, and revealing not just complementarity but a greater continuity between ASC and ACS from a republican perspective.

The framing assumptions outlined by Bauböck that I am taking as agreed and will not discuss further include the following: Democracy is independently valuable, not just a means to justice. For both empirical and normative reasons, there will be a plurality of democratic polities, which will, in foreseeable practice, be territorial - that is, they will take the form of bounded spaces within which political power is exercised over human beings and laws applied to them. In territorial states, the best proxy for subjection is residence. ${ }^{1}$ Democratic politics needs continuity over time, and thus depends on a relatively sedentary (but not static) population, or is more difficult to realize with hypermobility between polities. Furthermore, accepting the existence of borders does not mean accepting that those borders are necessarily sites of control.

While a case can be made that citizens abroad are subject in certain respects, whether this justifies membership of the demos is a matter of debate (Owen 2009, 2012). 
Likewise, I accept that there are good empirical and normative reasons why the demos cannot be defined on the basis either of a pre-political entity such as the nation, or of voluntary consent, as in the social contract tradition. Largely involuntary in membership, the political community is less than the political expression of a pre-political people, but more than an association or agreement on procedures. Furthermore, I also adopt a republican approach in which individual autonomy is connected with participation in collective self-government.

Turning to the principles proposed as criteria for membership of the demos, I accept the argument that the all affected principle cannot define the ground for the protection of rights or membership of the political demos, though it does provide good reasons for requiring states to take into account the interests of all those significantly affected by political decisions.

\section{Interpreting the all subjected principle}

As presented by Bauböck, the all subjected principle provides for protection of the rights of those who are subject to coercion. "The ASC principle captures the idea that the democratic legitimacy of government coercion depends on securing equal liberties for all whose autonomy it restricts" (p. 28).

This is interpreted in terms of interference with individuals and failure to track their interests, as presented in the neo-republican account of non-domination articulated in particular by Philip Pettit (Pettit 1997, 2012). This requires that there be institutional constraints on government and that those subjected have the opportunity to contest exercises of power over them, but it does not constitute self-government. On this account, the people are like editors rather than authors of government, or, as Bauböck puts it, government is accountable to, but not authorized by them. From his perspective this is a serious drawback for the claim that the all subjected principle should be the basis of the demos: "This shortcoming makes neo-Roman republicanism a 
somewhat limited perspective for a comprehensive theory of democratic inclusion, but one that has elective affinity with the ASC principle and is well suited to provide normative support for it" (p. 34). For him, non-domination could be achieved by a paternalistic government which tracked the interests of those subjected, and it does not require democracy at all.

Our attention is drawn to the fact that this diverges from an older republican tradition in which individual autonomy and collective selfgovernment are linked, and the people authorize - not merely check - government. While bringing participation in collective self-government to the fore, that tradition has encountered some hostility because of the tendency to identify "the people" as a unitary subject that may threaten to dominate individuals and minorities.

Before considering the possibility of reformulating the conception of the people in the self-government tradition, I unpack the interpretation of neo-republican non-domination and its implications for democracy. This unpacking suggests that the requirements of non-domination are not as separate from republican self-government as they may at first appear. We may first of all say that domination is indeed expressed in terms of interference, but it is not just a matter of particular interference. If it were a matter of particular cases of interference in interests, it would fit better with the all affected principle - and indeed connections with, and similarities to, that principle have been identified by others - and contestation could be seen as appropriate for affected interests (e.g. Näsström 2011: 122, n. 5). But, as Bauböck correctly assesses, "vulnerability to arbitrary interference is a condition in which individuals find themselves as the result of exposure to coercive government institutions rather than to negative externalities of particular decisions" (p. 34); it thus provides normative support for ASC.

Thus there is more to non-domination than the protection of interests against specific interference. It opposes the condition of subjection to coercion that renders arbitrary interference always possible. But there has been some indeterminacy between interests and will in expressions of neo-republican theory. The emphasis in Pettit's account of domination 
has varied between the failure to track interests and the imposition of an arbitrary will (Markell 2008; Lovett 2010). An emphasis on tracking interests may not require democratic self-government - or requires only a weaker version of democracy. As Pettit puts it, "[d]emocracy is not inherently a collective matter, then; it is not inherently a matter of active control, and it is not inherently the sort of system that confines decision-making to sites that are available to public scrutiny and influence" (Pettit 2000: 140).

This account of republicanism, in which non-domination is closely linked to non-interference, is compatible with a kind of protective liberal politics - dealing with negative freedom, albeit a more secure negative freedom. Thus, on this basis, Bauböck judges that "ASC is rooted in a liberal conception of democracy as the system of political rule that is most likely to guarantee fundamental rights" (p. 48). Likewise he sees it, like liberal politics, as dealing mainly with individual-state relations rather than relations of self-governing citizens.

But Pettit has at some points expressed what is at stake in domination not as a failure to track a range of interests, but as the continuing threat of the imposition of the arbitrary will of another. Then what non-domination realizes is not tracking the interests of subjects, but removing the power of that continuing threat. ${ }^{2}$ In the first instance, this amounts to the replacement of mastery by "non-mastery" (Pettit 1997: 22). This requires more than liberal institutional protections constraining government, guaranteeing and publicly recognizing the equal status of citizens; it also depends on mutual recognition by citizens of one another as equal and of non-domination as a common good that can only be realized collectively, depending on citizens internalizing the value of non-domination as well as having the standing to contest laws and policies (Pettit 1997). While Pettit defines the institutional

2 That this is specifically within relationships of dependence is made clear in Lovett's reformulation of domination: "Persons or groups are subject to domination to the extent that they are dependent on a social relationship in which some other person or group wields arbitrary power over them" (Lovett 2010: 119). 
provisions this requires mainly in terms of constraints on government, other theorists of non-domination have argued that more substantial political power of the people or their representatives relative to rightsprotecting institutions is required for non-domination (Maynor 2003; Bellamy 2007).

It may be argued further that the point of non-domination, or nonmastery, is to allow for individual autonomy. Non-domination may be seen then as an essential precondition for personal autonomy. Pettit sees this as beyond the domain of politics, maintaining that non-domination is compatible with personal autonomy and that republican institutions facilitate this indirectly, but argues that personal autonomy does not have to be a concern of republican politics: "people can be trusted to look after their own autonomy, given that they live under a dispensation where they are protected from domination by others" (Pettit 1997: 83).

As domination precludes the exercise of individual and collective autonomy, non-domination may be seen as the condition for autonomy. Autonomy, moreover, like non-domination, cannot be exercised individually, or understood in purely private terms. Thus political autonomy can be seen as a natural extension of personal autonomy, or, as Habermas puts it, private and public autonomy are "equiprimordial" or equally fundamental:

In the final analysis, private legal persons cannot even attain the enjoyment of equal liberties unless they themselves, by jointly exercising their autonomy as citizens, arrive at a clear understanding about what interests and criteria are justified and in what respects equal things can be treated equally and unequal things unequally in any particular case. (Habermas 1994: 113)

If we follow this line of thinking, we move beyond the protection of interests to participation in collective self-government. There seem, then, to be two alternatives in considering non-domination as the basis of ASC: we can interpret it in terms of interests, in which case it collapses back into AAI, or in terms of facilitating autonomy, when it leans towards a stronger norm of participation in collective self-government. 


\section{Reconsidering a republican account of the all subjected principle}

If self-government is seen as entailed by the need for non-domination, and to realize autonomy among those who are interdependent, we may propose a modified republican formulation of the all subjected principle, in which the demos is composed of those who share a wide range of multiply reiterated interdependencies, which have been significantly shaped by their subjection to a common authority. They have not constituted themselves voluntarily as a demos, but have been thrown together historically; they share not only a common past, but also (putatively) a common future; they are faced by issues that can only be addressed, and goods that can only be realized, collectively. If they can act collectively as citizens they may be able to determine their future - to be part-authors, if not wholly in control of their lives. They become a demos through the practice or even the open possibility of collective public interaction (Honohan 2002: 266).

But Bauböck identifies certain obstacles to ASC as the basis for determining membership in a self-governing citizenry. First and foremost, this seems to root self-government only in subjection, and cannot identify the links that make a people a candidate for self-government. It involves a circular argument that the demos is constituted by the impact of the government that can only be constituted by the same demos.

The ASC principle, it is argued, allows prior subjection to be the determinant of the shape of the political community. It lacks a "conception of political membership linking individual inclusion claims to collective claims to self-government and a conception of political community that is not limited to sovereign states" (p. 30). But, it may be argued against this, continuing exposure to political authority does have the effect of framing interdependence in such a way as to make self-government between people necessary. Within states over time, interdependencies grow, making individual personal and political autonomy more interdependent on others than before. Even in the contemporary context of globalization, the authority of bounded states has the effect of creating multiply reiterated relations of interdependence. 
The second issue is that ASC involves an inherent bias towards existing boundaries. This is true, but there may be reasons to be biased towards existing boundaries - in the way in which, as I have noted, they come to determine all kinds of interdependencies, and constitute the demos who have a future together and the possibility of collectively determining it. We may accept them also, as many theorists have done, in the absence of a convincing alternative principle on the basis of which a demos can constitute itself.

But a further issue arises - that it is not clear that all forms of subjection justify inclusion in the demos. Bauböck poses the problem cases of the U.S. occupation of post-World War 2 Germany and the Algerian independence movement. In these cases, he points out, the subjection involved could not be seen as requiring or being remediated by inclusion in the demos of the sovereign state. But in the German case, the temporary nature of the subjection may be thought to ground the need for protection and contestation rather than inclusion. ${ }^{3}$ Moreover, if we formulate the demos of collective self-government in terms of those whose multiple relationships of interdependence have been shaped by subjection to a state, it does not follow that its bounds will be identical to those of that sovereign state. Not all boundaries create a single people, but a democratic people may be created by subjection within a boundary. In the case of Algeria (and other colonies), the grounds for the demos could be thought to reflect the fact that Algerian subjection to France was different from that of French citizens in France. Algeria could not be seen as part of the same web of reiterated interdependencies as those in metropolitan France. Likewise, although two colonies remote from one another might have common cause, this does not mean that their subjection to a single colonial power made them a single demos. A colony without statehood may be a candidate for self-government because the people there have become increasingly interdependent through their subjection within a bounded polity. The grounds lie in their need for autonomy rather than their capacity, and do not depend in the nineteenth century, but that is not essential to the argument here. 
on their constituting a prior "people" in the conventional sense. Rather than being irredeemably backward-looking, this account of the demos based on the all subjected principle balances backward- and forwardlooking elements.

Thus the possibility of a people's collective self-government does not depend (unlike the approach of Stilz that Bauböck criticizes) on their "history of political cooperation by sharing a state ... in the recent past" or their demonstrable capacity to "reconstitute and sustain a legitimate state" today (p. 30, quoting Stilz 2011: 591) so much as that they find themselves in the circumstances where collective action is required for the possibility of self-government.

On this view the demos is a relatively stable set of people who face a common predicament, share common risks and common goods, who may realize - or fail to realize - the possibility of securing nondomination and jointly exercising some collective control over their lives. Accordingly this interpretation of ASC reveals what Bauböck sees as a necessary "correspondence between individuals' interests in autonomy and well-being and the collective interests of all citizens in their polity's self-government and flourishing" (p. 41). It does not involve an essentialist view of "the people" (pre-political or otherwise), who constitute a unitary body with a single will.

Even if citizens of self-governing polities are initially constituted through common subjection, their coming to authorship in selfgovernment can be thought of as an incremental possibility. ${ }^{4}$ While my account may still be seen as "statist" in the sense that it arises from former subjection to a state and accepts a starting point of existing borders, it does not imply that it is impossible to go beyond these borders; rather it acknowledges that the state remains one of the strongest determinants of continuing subjection and interlocking interdependencies.

4 This incremental justification may be compared with similar accounts of social contract theory as recognizing as legitimate states that acquire emergent consent over time (e.g. Hampton 1998, who identifies the possibility of moving from a weak consent to government - convention consent - to active support of a particular form - endorsement consent). See also Pettit's more narrowly focused discussion of a constituting and a constituted people (Pettit 2012: 285-190). 
As Bauböck points out in section 4.1, the possibility of domination between and across states may call for political authorities at higher and lower levels. $^{5}$

Among other difficulties identified with ASC as the basis of inclusion in the demos is the fact that it may be over-inclusive in several ways. First, it does not exclude temporary visitors and tourists, who are subject as long as they are present in the country. But temporary rather than continuing subjection does not constitute the same threat of domination as longer-term residence, and requires protection rather than membership of the demos. The possibility of voluntary exit reduces the risk of domination. But the longer a person is resident the greater may be the costs of leaving and the risk of domination; thus long-term residents generally need a voice and membership of the demos (Lovett 2010; Benton 2014).

This does indeed, as Bauböck notes, lead logically to mandatory citizenship for long-term residents. He sees residence as an appropriate basis for the local political demos, but not for membership of the larger political community, where people should be able to choose whether to acquire a new citizenship status. There are convincing arguments, however, that mandatory citizenship can be justified on the basis that citizens' capacity for self-determination and their realization of common goods are undermined if many of those linked in interdependencies subject to the state do not have a political voice. ${ }^{6}$ This is not just a matter of individual protection. As de Schutter and Ypi have argued, it creates an unfair asymmetry in the distribution of political obligations between citizens and immigrants; non-citizen long-term residents are

5 The idea of domination (more than simple subjection at a point in time) supports the proposal for multilevel citizenship - as the larger unitary polities become, the more risk of domination of minorities within those states (p. 59); maintaining or extending the devolution of power to local and regional levels, and also calling for the creation of supranational institutions and polities where the threat of domination prevents collective decision-making or action (p. 60). "The dispersal and pooling of sovereignty at substate and suprastate levels reduces the risk of political domination within states and enhances opportunities for democratic self-government beyond the state" (p. 57).

6 This may be seen as parallel to the suggestion that the inclusion of non-resident citizens without a real connection to the demos undermines citizen self-government. 
(willing or unwilling) free riders, weakening the possibilities of selfgovernment (de Schutter and Ypi 2015). ${ }^{7}$ Having a say where one is subject to coercion, in relations of interdependence and cooperating with others in shaping the future common life should not be a matter of choice. If dual or multiple memberships become increasingly accepted by states, this reduces the difficulties with respect to mutual obligations between independent states.

Finally, is the claim of ASC undermined by the fact that, at least on an expanded account of what counts as subjection, it suggests that those coerced by migration laws should be part of the demos that determines those laws? (Abizadeh 2008). On the one hand, it can be argued that migration laws sufficiently dominate those who have good reasons to migrate to justify at least consideration of their affected interests and, arguably, a range of protections and contestation (Honohan 2015). But, however significant for individuals and their life chances, if the coercion involved does not add up to continuing subjection, it may not provide grounds for full inclusion in the existing polity (though this also may call for a polity at higher levels).

When it comes to necessary inclusions, Bauböck acknowledges that the ASC principle can clearly include those who may not easily be seen as active political participators, for example those with cognitive limitations and very young children, who are subjected and share a common future in the state. On certain accounts of autonomy and political capacity, perhaps, it might be thought that they are less easy to include. But, while they may differ in capacity for autonomy or participation in self-government, it is important first that they are not subject to domination, and that their opportunity to participate in proportion to their (hitherto seriously underestimated) capacity for autonomy be facilitated.

This roughly corresponds to just one of de Schutter and Ypi's arguments - that based on equal burden-sharing, including a duty to become part of the demos: "Preserving public goods needs political management. And the latter is in turn difficult without a collective 'we' that is required to mobilize politically in order to uphold common institutions" (de Schutter and Ypi 2015: 241). They develop three other arguments, based on affectedness, equal citizenship and stability that I do not rely on here. 


\section{Birthright citizenship and the continuity of the political community}

Bauböck acknowledges that, unlike AAI and ASC, ACS does not immediately provide a clear ground for including newborn children. But he justifies their inclusion as needed to fulfil the conditions for continuity of a self-governing polity over time. He sees birthright citizenship (both ius soli and ius sanguinis) as a better way to establish this continuity than basing citizenship on residence (while allowing also for adjustments through naturalization and voluntary renunciation in response to mobility in later life). ${ }^{8}$ Birthright citizenship allocates membership to new generations that are born without the need for potentially divisive individual decisions or determinations in each case, and makes citizens aware that they are part of an intergenerational community. This is, he says, at least compatible with ACS. ${ }^{9}$

He rejects the argument that birthright citizenship is analogous to inherited property rights. But, even if citizenship is not appropriately seen as property, it could be said that awarding birthright citizenship facilitates the transmission of privilege in the interest of the continuity of the polity. On some views children entering society should logically be seen as similar in all significant respects to immigrants entering (or seeking to enter) as strangers (e.g. Brezger and Cassee 2016). I suggest that the all subjected principle, understood as future-oriented interdependence in continuous subjection, for which residence is a proxy, provides a more defensible ground for birthright citizenship.

Forward-looking interdependence in subjection to authority can ground provisional ius soli membership for those born in the state, depending on continuing residence, and conditional ius sanguinis membership for those born to citizens abroad, retained only if residence

The alternative would be to allow membership only at majority.

9 Bauböck acknowledges that there is more to said here, however: "Birthright citizenship is certainly not a sufficient answer to this challenge, but it may be a necessary one once we consider the alternative of grounding all political memberships on residence" (pp. 88-9). 
in the state is subsequently established (cf. Honohan 2015). There are many practical reasons for granting citizenship at birth rather than postponing it until adulthood. These include the need of children for protection and the chance to live and move with their families while they are children, even if (arguably) they are not eligible to be members of the demos until adulthood.

\section{Conclusion}

Bauböck's work has established clearly that we have to deal with questions not just of inclusion or exclusion from the demos, but with a whole panoply of full and partial claims for membership in the demos, to citizenship and to access of various kinds, ranging from consultation through protection to participation in self-government, and that these arise at multiple levels. The citizenship stakeholder account allows for recognition of this panoply of claims. It facilitates their incorporation by articulating the grounds for membership at a more general level of abstraction. Nonetheless, it requires considerable interpretation and specification in more concrete cases.

This discussion suggests that the appropriate images for thinking about the terrain of democratic membership are neither a flat landscape with separate states demarcated by linear boundaries, nor radiating circles of those whose interests are affected to diminishing degrees with distance, nor even a three-dimensional terrain of occasional supranational hills and many deeper subdivisions within states. On reading this essay, we might conclude that the complexity of membership claims needs geological images of layered structures, with multidimensional and cross-cutting tectonic plates that overlap partially but not fully.

Both Bauböck's and my accounts recognize a difference between the membership of the active demos and the citizenry: "A stakeholder conception does therefore suggest a distinction between the demos, consisting of all those who have the franchise, and the citizenry, composed 
of all who have a stake in being members of a transgenerational political community" (p. 46). The bundle of rights and duties we conventionally associate with citizenship may be subject to certain kinds of disaggregation. On my account, the protections of citizenship may need to be applied more widely and in a more capacious time-frame than membership of the demos. Thus while ACS provides a general account of grounds for membership at the most abstract level, and is pluralist in seeing different principles as appropriate at different levels, the all subjected account here may define membership of the demos more clearly on the basis of a single principle, but the account of citizenship needs to be pluralist, mainly by building in a temporal cushion with respect to subjection. Even when there is no firm basis for membership of the demos, individuals need protection, and to maintain family and other connections within states, for example. Citizenship may, for practical reasons, be retained with a lag when an individual citizen moves to another country, be awarded with a time-lag after arrival as a permanent immigrant resident, and be held conditional on residence for children born in the country or to citizens.

I have suggested that the all subjected principle provides grounds for determining membership of a republican political community for those interdependent in continuing subjection to a political authority. This account has much in common with the citizenship stakeholder account based on a legitimate stake in participating in the self-government of a particular political community. But it may be argued that the clearest and most significant stake in membership derives from continuing subjection, and that the all subjected principle provides a clearer criterion for membership of the demos, and can ground an account of republican self-government of the kind that Bauböck endorses.

\section{References}

Abizadeh, Arash. 2008. "Democratic Theory and Border Coercion: No Right to Unilaterally Control Your Own Borders." Political Theory 36 (1): 37-65. 
Bellamy, Richard. 2007. Political Constitutionalism: A Republican Defence of the Constitutionality of Democracy. Cambridge: Cambridge University Press. Benton, Megan. 2014. "The Problem of Denizenship: A Non-domination Framework." Critical Review of International Social and Political Philosophy 17: 49-69.

Brezger, Jan and Andreas Cassee. 2016. "Debate: Immigrants and Newcomers by Birth - Do Statist Arguments Imply a Right to Exclude Both?” Journal of Political Philosophy 24 (3): 367-378.

de Schutter, Helder and Lea Ypi. 2015. "Mandatory Citizenship for Immigrants.” British Journal of Political Science. 45 (2): 235-251.

Habermas, Jurgen. 1994. "Struggles for Recognition in the Democratic Constitutional State." In Multiculturalism, edited by C. Taylor and A. Gutmann. Princeton: Princeton University Press: 107-148.

Hampton, Jean. 1998. Political Philosophy. Boulder: Westview.

Honohan, Iseult. 2002. Civic Republicanism. Abingdon and New York: Routledge.

Honohan, Iseult. 2015. "Limiting the Transmission of Family Advantage: Ius Sanguinis with an Expiration Date." In Bloodlines and Belonging: Time to Abandon Ius Sanguinis?, edited by C. Dumbrava and R. Bauböck. Florence: EUI Robert Schuman Centre for Advanced Studies: 32-34.

Lovett, Frank. 2010. A General Theory of Domination. Oxford: Oxford University Press.

Markell, Patchen. 2008. “The Insufficiency of Non-domination.” Political Theory 36 (1): 9-36.

Maynor, John. 2003. Republicanism in the Modern World. Cambridge: Polity. Näsström, Sofia. 2011. “The Challenge of the All Affected Principle.” Political Studies 59 (1): 116-134.

Owen, David. 2009. "Resident Aliens, Non-resident Citizens and Voting Rights." In Citizenship Acquisition and National Belonging, edited by G. Calder, P. Cole and J. Seglow Basingstoke: Palgrave: 52-73.

Owen, David. 2012. "Constituting the Polity, Constituting the Demos: On the Place of the All Affected Interests Principle in Democratic Theory and in Resolving the Democratic Boundary Problem.” Ethics and Global Affairs 5 (3): 129-152. 
Pettit, Philip. 1997. Republicanism: A Theory of Freedom and Government. Oxford: Oxford University Press.

Pettit, Philip. 2000. "Democracy, Electoral and Contestatory." In Designing Democratic Institutions, edited by I. Shapiro and S. Macedo.. New York: New York University Press: 105-142.

Pettit, Philip. 2012. On the People's Terms: A Republican Theory and Model of Democracy. Cambridge: Cambridge University Press.

Stilz, Anna. 2011. "Nations, States, and Territory." Ethics 121 (3): 572-601. 